\title{
KERÄSALAATIN VARASTOINTI
}

\author{
IRMA VOIPIO \\ Helsingin yliopiston puutarhatieteen laitos, Viik
}

Saapunut 20. 10. 1965

Salaatin laatu on paras heti korjuun jälkeen. Jo muutamassa tunnissa se huoneen lämmössä säilytettynä menettää vettä ja sen ulkonäkö ja maku huononevat. Nykyäån on harvoin mahdollista korjata salaattia juuri ennen käyttöä. Salaattia viljellään usein seuduilla, joilta tuotteet markkinoidaan pitkien kuljetusmatkojen taakse. Siitä johtuu, että salaattia kuljetetaan ja säilytetään korjuun jälkeen useankin vuorokauden ajan, ennen kuin se joutuu kulutukseen. Kuljetus- ja varastotilojen soveltuvuus salaatin säilyttämiseen on sen vuoksi tärkeää, jotta laatu pysyisi hyvänä. Koska salaatin korjuukausi on lyhyt, muodostuu markkinoille usein ruuhkaa, ja toisaalta salaattia korjataan runsaan kysynnän takia usein ennen sen valmistumistakin. Muutaman viikon varastoinnilla voidaan tasoittaa markkinoita, mutta se vaatii asianmukaisia varastotiloja sekä varastoimismenetelmien selvittämistä.

Salaattia voidaan kirjallisuustietojen mukaan säilyttää varastossa, jossa lämpötila on $0^{\circ}$ ja ilman suhteellinen kosteus $90-95 \%$. Tällaisessa varastossa sen on todettu säilyvän pari kolme viikkoa (8). Usein pidetään tärkeänä, että ns. lehtivihannekset heti korjuun jälkeen jäähtyvät nopeasti. Tätä silmällä pitäen on kehitetty erilaisia jäähdytysmenetelmiä, kuten kylmävesi-, tyhjiö- ja kylmäilmajäähdytystä; näiden merkitystä salaatin käsittelyssä ovat tutkineet mm. DEwLY (4), Cook (1), Friedman ja Radspinner (3) sekä Stewart (9). Paitsi lämpötilaa alentamalla on myös erilaisin kemikaalein pyritty hidastamaan vihannesten sadonkorjuun jälkeistä elintoimintaa. Näistä viimeisiä on $\mathrm{N}_{6}$-bentsyladeniini (valmisteen nimi SD 4901), jonka on useissa tutkimuksissa todettu parantaneen salaatin säilyvyyttä $(2,5,11)$.

Helsingin Yliopiston puutarhatieteen laitoksella ryhdyttiin v. 1963 selvittämään, kuinka suuret salaatin varastointitappiot erj pituisten varastointijaksojen päätyttyä ovat, sekä niitä keinoja, joilla varastointitappioita voidaan pienentää. 


\section{Aineisto ja menetelmät}

Salaattiaineisto kasvatettiin Viikissä Puutarhatieteen laitoksen koekentällä. Tutkittavina olivat pehmeät keräsalaatit Herttaässä ja Market Favorite sekä rapea keräsalaatti Great Lakes. Ne kylvettiin kesäkuun alussa avomaalle (taulukko 1). Peruslannoituksena annettiin puutarhan Y-lannoitetta $10 \mathrm{~kg} / \mathrm{a}$ ja pintalannoituksena kalkkisalpietaria $2 \mathrm{~kg} / \mathrm{a}$. Sadonkorjuuseen (taulukko 1) ryhdyttiin kun salaatit saavuttivat korjuukypsyyden eli olivat muodostaneet lajikkeelle ominaisen kerän. Varastoitavaksi valittiin vain I laatuluokkaa vastaavaa satoa (vrt. 12).

Taulukko 1. Salaatin kylvö-, harvennus- ja korjuuaika, sadon lämpötila sekä varastoidun salaatin määrä. Table 1. Sowing, thinning and harvesting time of lettuce, temperature of crop and the stored lots in different seasons.

\begin{tabular}{|c|c|c|c|c|c|c|}
\hline $\begin{array}{l}\text { Vuosi } \\
\text { Year }\end{array}$ & $\begin{array}{l}\text { Lajike } \\
\text { Variety }\end{array}$ & $\begin{array}{l}\text { Kylvö } \\
\text { Sowing }\end{array}$ & $\begin{array}{l}\text { Harvennus } \\
\text { Thinning }\end{array}$ & $\begin{array}{c}\text { Sadonkorjuu } \\
\text { alkaa } \\
\text { Harvesting } \\
\text { starts }\end{array}$ & $\begin{array}{c}\text { Kerien } \\
\text { lämpötila } \\
{ }^{\circ} \mathrm{C} \\
\text { Tempera- } \\
\text { ture of } \\
\text { heads }{ }^{\circ} \mathrm{C}\end{array}$ & $\begin{array}{c}\text { Varastoitu } \\
\text { kg } \\
\text { Weight of } \\
\text { stored lots, } \\
\text { kg }\end{array}$ \\
\hline 1963 & $\begin{array}{l}\text { Herttaässä } \\
\text { (Passe Partout) }\end{array}$ & 7. 6 . & 2. 7 . & 31. 7 . & $22-24$ & 45 \\
\hline 1964 & $\begin{array}{l}\text { Herttaässä } \\
\text { Market Favorite } \\
\text { Great Lakes }\end{array}$ & $\begin{array}{r}11.6 . \\
11.6 . \\
2.6 .\end{array}$ & $\begin{array}{l}26.6 .-2.7 . \\
27.6 .-2.7 \text {. } \\
23 .-25.6 \text {. }\end{array}$ & $\begin{array}{l}7.8 . \\
12.8 . \\
17.8 .\end{array}$ & $\begin{array}{l}13-14 \\
13-14 \\
13-23\end{array}$ & $\begin{array}{r}239 \\
46 \\
548\end{array}$ \\
\hline 1965 & $\begin{array}{l}\text { Herttaässä } \\
\text { Market Favorite } \\
\text { Great Lakes }\end{array}$ & $\begin{array}{r}11.6 . \\
11.6 . \\
2.6 .\end{array}$ & $\begin{array}{l}30.6 . \\
30.6 . \\
28.6 .\end{array}$ & $\begin{array}{l}12.8 . \\
23.8 . \\
17.8 .\end{array}$ & $\begin{array}{l}12-18 \\
20-22 \\
18-24\end{array}$ & $\begin{array}{r}368 \\
29 \\
623\end{array}$ \\
\hline
\end{tabular}

Kustakin salaattierästä mitattiin sadonkorjuulämpötila kerien sisältä, minkä jälkeen erät punnittiin ja käsiteltiin. Kylmävesijäähdytys suoritettiin v. 1963 suihkuttamalla salaattia 15 minuutin ajan +2 -asteisella vedellä, ja vuosina $1964-65$ upottamalla kasvinosat 15 minuutiksi $2^{\circ}$ :n veteen. Pesu vedellä suoritettiin siten, että salaatit upotettiin $15-30$ sekunnin ajaksi $15^{\circ}$ :n veteen, ja SD 4901 -käsittelyt upottamalla salaatit käsittelyliuokseen, jonka lämpötila oli $15^{\circ}$. Muovipussit, joihin salaatti pakattiin, olivat $1 \mathrm{~m}: n$ pituisia ja $35 \mathrm{~cm}$ leveitä. Pussi suljettiin molemmista päistä kumirenkailla ja rei'itettiin. Pussiin tehtiin 16 reikää, joiden läpimitta oli $5 \mathrm{~mm}$. Jäähilekäsittelyssä kaadettiin kunkin valmiiksi pakatun salaattilaatikon päälle 2 litraa jäähilettä.

Kunakin vuonna oli koejäsenissä viisi kerrannetta, joissa 10 kerää. Nämä pakattiin puulaatikoihin $(60 \times 39 \times 16 \mathrm{~cm})$ kanta alaspäin. Salaatit varastoitiin tutkimuskellariin, jossa ilman lämpötila oli $1-2^{\circ}$ ja suhteellinen kosteus $90-95 \%$.

Varastoimisajan päätyttyä salaattierät punnittiin haihtumistappioiden määräämiseksi, kunnostettiin, so. salaateista poistettiin nahistuneet, mädäntyneet tai muutoin vioittuneet lehdet, ja punnittiin uudelleen. Varastoimisajan jälkeen arvosteltiin 
kauppakuntoisiksi salaatit, jotka vastasivat joko ensimmäistä tai toista laatuluokkaa (vrt. 12). Tulokset ilmoitetaan prosentteina alkuperäisestä ennen käsittelyä ja varastointia olleesta kunnostetun tavaran painosta.

\section{Tulokset}

Vuoden 1963 varastointikokeet. Vuonna 1963 varastoitiin salaattia (Herttaässä) käsittelemättömänä muovipussiin pakattuna sekä kylmällä vedellä jäähdytettynä.

Salaatin lämpötila oli ennen jäähdytystä $24^{\circ}$ ja jäähdytyksen jälkeen $10^{\circ}$. Kylmävesikäsittelystä aiheutunut painon lisäys oli $20-30 \%$. Tulokset näistä kokeista esitetään taulukossa 2 .

Taulukko 2. Salaatin (Herttaässä) varastointikoe v. 1963.

Table 2. Experiment on storing lettuce (Passe Partout) in 1963.

Prosentit laskettu ennen käsittelyä ja varastointia kunnostetun salaattierän painosta.

Based on the weight of saleable lettuce before treatment and storage.

\begin{tabular}{|c|c|c|c|c|c|c|}
\hline \multirow[t]{2}{*}{$\begin{array}{l}\text { Käsittely } \\
\text { Treatment }\end{array}$} & \multicolumn{2}{|c|}{$\begin{array}{c}\text { Salaatin paino }(\%) \text { varastoin- } \\
\text { nin jatkuttua } \\
\text { Weight of lettuce }(\%) \text { after } \\
\text { storage period of }\end{array}$} & \multirow[b]{2}{*}{$\begin{array}{l}30 \text { päivää } \\
30 \text { days }\end{array}$} & \multirow{2}{*}{$\begin{array}{c}\text { Kunnostettu } \\
\text { paino } 30 \text { päi- } \\
\text { vän kuluttua } \\
(\%) \\
\text { Trimmed } \\
\text { weight after } \\
30 \text { days } \\
(\%)\end{array}$} & \multicolumn{2}{|c|}{$\begin{array}{l}\text { Varastointi- } \\
\text { tappiot \% } \\
\text { Storage losses } \\
\%\end{array}$} \\
\hline & $\begin{array}{l}14 \text { päivăä } \\
14 \text { days }\end{array}$ & $\begin{array}{l}21 \text { påivää } \\
21 \text { days }\end{array}$ & & & $\begin{array}{l}\text { Kokonais } \\
\text { Total }\end{array}$ & $\begin{array}{l}\text { Haih- } \\
\text { dunta } \\
\text { Evapo- } \\
\text { ration }\end{array}$ \\
\hline $\begin{array}{l}\text { Käsittelemätön } \\
\text { Untreated }\end{array}$ & $88.5 \pm 0.57$ & $83.9 \pm 0.72$ & $80.0 \pm 0.86$ & $25.3 \pm 6.08$ & 74.7 & 20.0 \\
\hline $\begin{array}{l}\text { Pakkaus muoviin } \\
\text { Wrapped in PV-bags }\end{array}$ & $99.5 \pm 0.10$ & $99.4 \pm 0.18$ & $99.3 \pm 0.31$ & $44.4 \pm 11.05$ & 55.6 & 0.7 \\
\hline $\begin{array}{l}\text { Kylmävesi- } \\
\text { jäähdytys } \\
\text { Hydrocooling }\end{array}$ & $112.6 \pm 12.96$ & $102.2 \pm 5.83$ & $92.5 \pm 10.50$ & $26.2 \pm 6.96$ & 73.8 & $(7.5)$ \\
\hline
\end{tabular}

Kahden viikon varastoinnin jälkeen oli käsittelemättömän erän painonvähennys $11.5 \%$ ja muoviin pakatun erän $0.5 \%$. Kylmällä vedellä jäähdytetyn erän paino oli $12.6 \%$ suurempi kuin alkuperäinen paino. Taulukosta 2 selviää myös, että kuukauden pituisen varastoinnin jälkeen käsittelemättömät erät olivat menettäneet haihdunnan takia $20 \%$ ja muoviin pakatut noin $1 \%$ :n painostaan. Kylmällä vedellä käsiteltyjen erien haihtumistappio oli $7.5 \%$. Kauppakelpoiseksi kunnostuksen jälkeen oli käsittelemättömien ja kylmällä vedellä käsiteltyjen erien paino noin $25 \%$ ja muoviin pakattujen erien $44 \%$ alkuperäisestä painosta.

Vuoden 1964 varastointikokeet. Vuonna 1964 jatkettiin salaatin varastointikokeita selvittämällä eri pakkaustapojen, kylmävesikäsittelyn, 15 -asteisella vedellä pesun, muovipakkauksen ja SD 4901:n vaikutusta.

Pakkaustapakoe, joka käsitti kolme erilaista pakkaustapaa, kesti kolme viikkoa (taulukko 3). Tilastollisesti tuloksia tarkastettaessa ei pakkaustapa näyttänyt 
vaikuttaneen salaatin säilyvyyteen. Kuitenkin Herttaässästä, joka oli pakattuna kanta ylöspäin, poistettiin kolmen viikon varastoinnin jälkeen runsaasti lehtiä, koska nämä olivat varastoinnin aikana. vioittuneet laatikon pohjaa vasten. Kanta ylöspäin pakatusta Herttaässästä oli haihtunut vettä noin $10 \%$ vähemmän kuin muilla tavoin pakatusta Herttaässästä. Great Lakesin varastointitappiot johtuivat ensimmäisenä viikkona vain haihtumisesta, mutta jo toisella viikolla tapahtui

Taulukko 3. Salaatin varastointikoe erilaisin pakkaustavoin v. 1964 .

Table 3. Effect of different ways of packing on the keeping quality of letture in cold storage (temperature $1-2^{\circ} \mathrm{C}$, relative humidity $90-95 \%$.

Prosentit laskettu ennen varastointia kunnostetun salaattierän painosta.

Based on the weight of saleable lettuce stored.

\begin{tabular}{|c|c|c|c|c|c|c|c|c|c|c|}
\hline \multirow{3}{*}{$\begin{array}{l}\text { Pakkaustapa } \\
\text { Way of packing }\end{array}$} & \multirow{3}{*}{$\begin{array}{l}\text { Lajike } \\
\text { Variety }\end{array}$} & \multicolumn{3}{|c|}{$\begin{array}{c}\text { Kauppakelpoista salaattia (\%) jäljellä } \\
\text { varastoinnin jatkuttua } \\
\text { Percentage of lettuce saleable after storage } \\
\text { period of }\end{array}$} & \multicolumn{6}{|c|}{$\begin{array}{c}\text { Varastointitappiot } \% \\
\text { Storage losses } \%\end{array}$} \\
\hline & & 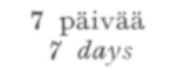 & $\begin{array}{l}14 \text { päivää } \\
14 \text { days }\end{array}$ & $\begin{array}{l}21 \text { päivää } \\
21 \text { days }\end{array}$ & \multicolumn{2}{|c|}{$\begin{array}{l}7 \text { päivää } \\
7 \text { days }\end{array}$} & \multicolumn{2}{|c|}{$\begin{array}{l}14 \text { pãivää } \\
14 \text { days }\end{array}$} & \multicolumn{2}{|c|}{$\begin{array}{l}21 \text { päiväă } \\
21 \text { days }\end{array}$} \\
\hline & & & & & 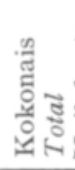 & 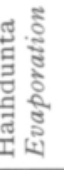 & 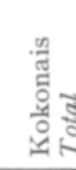 & 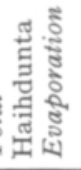 & 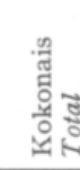 & 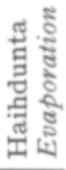 \\
\hline \multirow[t]{2}{*}{$\begin{array}{l}\text { Kanta alaspäin } \\
\text { Top upwards }\end{array}$} & $\begin{array}{l}\text { Hertta- } \\
\text { ässä } \\
\text { Great }\end{array}$ & $80.4 \pm 3.33$ & $63.9 \pm 4.72$ & $44.0 \pm 7.15$ & 19.6 & 9.1 & 36.1 & 12.9 & 56.0 & 22.1 \\
\hline & Lakes & $94.7 \pm 1.31$ & $63.5 \pm 10.05$ & $29.3 \pm 12.6$ & 5.3 & 5.3 & 36.5 & 6.6 & 70.7 & 15.0 \\
\hline \multirow[t]{2}{*}{$\begin{array}{l}\text { Kanta ylöspäin } \\
\text { Top downwards }\end{array}$} & $\begin{array}{l}\text { Hertta- } \\
\text { ässä } \\
\text { Great }\end{array}$ & $82.5 \pm 3.68$ & $63.2 \pm 6.74$ & $46.9 \pm 8.94$ & 17.5 & 8.6 & 36.8 & 13.0 & 53.1 & 14.4 \\
\hline & Lakes & - & $66.2 \pm 8.18$ & $38.8 \pm 14.49$ & - & - & 33.8 & 8.4 & 61.2 & 12.3 \\
\hline \multirow[t]{2}{*}{$\begin{array}{l}\text { Kyljellään } \\
\text { On the side }\end{array}$} & $\begin{array}{l}\text { Hertta- } \\
\text { ässä } \\
\text { Great }\end{array}$ & $81.1 \pm 2.60$ & $65.9 \pm 8.94$ & $37.5 \pm 4.99$ & 18.9 & 9.7 & 34.1 & 13.1 & 62.5 & 25.9 \\
\hline & Lakes & - & $63.7 \pm 22.20$ & $30.0 \pm 14.12$ & - & - & 36.3 & 10.1 & 70.0 & 13.1 \\
\hline
\end{tabular}

pilaantumista lähinnä fysiogeenisen lehdenreunataudin (tip burn) takia. Kunnostetun tavaran painon perusteella arvostellen Great Lakes säilyi yhtä hyvin kuin Herttaässä huolimatta sen pienemmistä haihtumistappioista.

Kylmällä vedellä käsitellyn Herttaässän paino oli yhden viikon varastoinnin jälkeen $91 \%$ (taulukko 4) ja käsittelemättömän vain $53 \%$ alkuperäisestä. Kahden viikon varastoinnin kuluttua olivat kylmällä vedellä käsitellyt Herttaässä sekä Great Lakes (taulukko 4) säilyneet hiukan paremmin kuin käsittelemätön ja 15asteisella vedellä pesty salaatti. Kolmen viikon kuluttua ei eroja kylmävesikäsittelyn hyväksi voitu todeta.

Kahden viikon varastoinnin kuluttua oli muoviin pakatussa Great Lakes-salaatissa kauppakelpoista n. $20 \%$ vähemmän kuin kontrollierässä. Kylmällä vedellä 
Taulukko 4. Salaatin varastointi v, 1964.

Table 4. Effect of different treatments on the keeping quality of lettuce in cold storage (temperature $1-2^{\circ} \mathrm{C}$, relative humidity $90-95 \%$ ) in 1964.

Prosentit laskettu ennen käsittelyä ja varastointia kunnostetun salaattierän painosta. Based on the weight of saleable lettuce before treatments and storage.

Käsittely

Treatment
Kauppakelpoista salaattia (\%) jäljellä varastoinnin jatkuttua

Percentage of lettuce saleable after storage period of 7 päivää 7 days
21 päivää 21 days
$\mathrm{H}$ e r t t a äs s ä

Käsittelemätön

Untreated

Pesu $15^{\circ}:$ lla vedellä

Washed with $15^{\circ}$ water

Kylmävesikäsittely

Hydrocooling

Great Lakes

Käsittelemätön

Untreated

Pesu $15^{\circ}:$ lla vedellä

Washed with $15^{\circ} \mathrm{C}$ water

Kylmävesijäähdytys

Hydrocooling

Pakkaus muoviin

Wrapped in $P V$-bags

Kylmävesijäähdytys + pakkaus muoviin

Hydrocooling $+P V$-bags

\begin{tabular}{|c|c|c|}
\hline $53.5 \pm 13.15$ & $39.0 \pm 11.08$ & $38.5 \pm 8.83$ \\
\hline $65.2 \pm 17.64$ & $36.0 \pm 7.60$ & $39.0 \pm 5.13$ \\
\hline $91.4 \pm 11.72$ & $48.6 \pm 8.45$ & $40.0 \pm 13.08$ \\
\hline $94.7 \pm 0.80$ & $63.5 \pm 10.00$ & $29.0 \pm 13.10$ \\
\hline- & $62.2 \pm 9.82$ & $9.7 \pm 7.49$ \\
\hline- & $67.8 \pm 15.09$ & $7.7 \pm 8.04$ \\
\hline- & $43.9 \pm 25.6$ & 0 \\
\hline- & $23.7 \pm 20.7$ & 0 \\
\hline
\end{tabular}

Taulukko 5. Salaatin (Great Lakes) käsittely SD 4901:llä v. 1964.

Table 5. Effect of SD 4901 treatments on the keeping quality of lettuce (Great Lakes) in cold storage (temperature $1-2^{\circ} \mathrm{C}$, relative humidity $90-95 \%$ ) in 1964.

Prosentit laskettu ennen käsittelyä ja varastointia kunnostetun salaattierän painosta.

Based on the weight saleable lettuce before treatments and storage.

Käsittely

Treatment

Kunnostetun salaatin paino (\%) 21 päivän varastoinnin jälkeen

Percentage of lettuce saleable after 21 days storage
Varastointitappiot \% Storage losses \%

Kokonais Haihdunta Total Evaporation

$\begin{array}{ll}71.0 & (3.3) \\ 66.4 & (3.5) \\ 74.6 & (4.6) \\ 57.3 & (2.3)\end{array}$

jäähdytetyssä ja muoviin pakatussa erässä oli n. $40 \%$ vähemmän kauppakelpoista tavaraa. Varastointiajan oltua kolme viikkoa ei muoviin pakattuja eriä voitu lainkaan kunnostaa.

Taulukossa 5 esitetään SD 4901 -käsittelyjen tulokset. 50 ppm SD 4901 -käsittely antoi parhaan tuloksen; kolmen viikon varastoinnin jälkeen oli kauppakelpoista 
Taulukko 6. Salaatin varastointi v. 1965.

Table 6. Effect of different treatments on the keeping quality of lettuce in cold storage (temperature $1-2^{\circ} C$, relative humidity $90-95 \%$ ) in 1965.

Prosentit laskettu ennen käsittelyä ja varastointia kunnostetun salaattierän painosta. Based on the weight of saleable lettuce before treatments and storage.

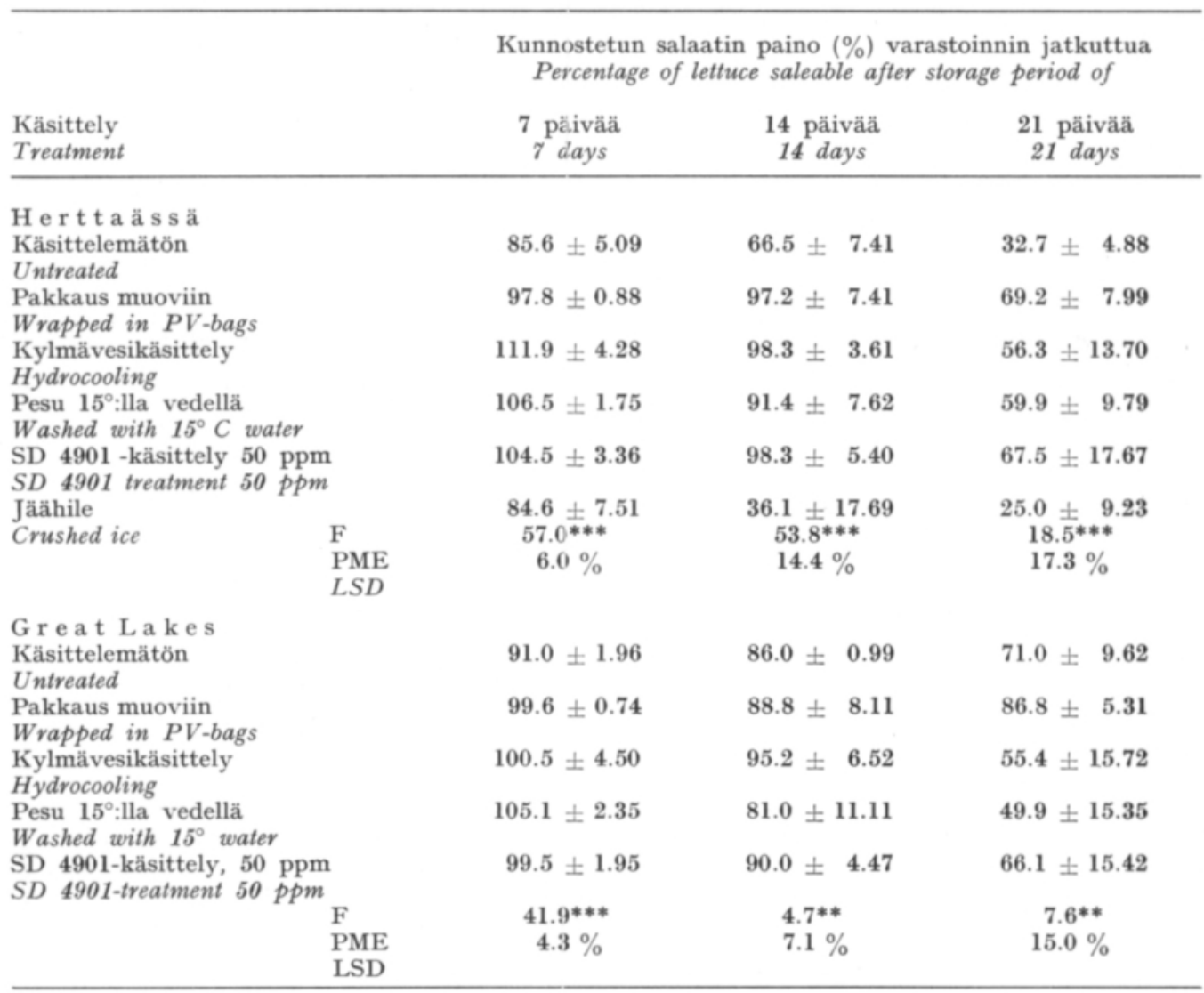

salaattia jäljellä $43 \%$. Sekä haihtumis- että kokonaistappiot olivat pienemmät $(2.3 \%$ ja $57.3 \%)$ kuin muulla tavoin käsitellyssä salaatissa.

Vuoden 1965 varastointikokeet. Vuonna 1965 toistuivat salaatin varastointikokeissa edellisinä vuosina parhaimmiksi osoittautuneet käsittelyt. Lisäksi suoritettiin jäähilekäsittelyjä.

Yhden viikon varastoinnin jälkeen osoittautui, että kylmävesikäsittely, pesu $15^{\circ}$ :n vedellä ja SD 4901 -käsittely ( $50 \mathrm{ppm}$ ) olivat parantaneet merkittävästi sekä Herttaässän että Great Lakesin (taulukko 6) säilyvyyttä varastossa. Toisen ja kolmannen viikon jälkeen oli tilanne sama ainoastaan Herttaässän kohdalla. Kylmävesikäsittely paransi selvästi Great Lakesin säilyvyyttä kahden viikon pituisen varastoinnin aikana. Muovipakkaus paransi sekä Herttaässän että Great Lakesin säilyvyyttä kontrollierään verraten, ja tulos oli kolmen viikon varastoinnin kuluttua kaikista käsittelyistä paras. Muoviin pakatun Herttaässän paino kunnostettuna oli $69 \%$ ja Great Lakesin $87 \%$ alkuperäisestä painosta. Kuvissa 1 ja 2 esitetään edellä mainitut tulokset graafisesti. 

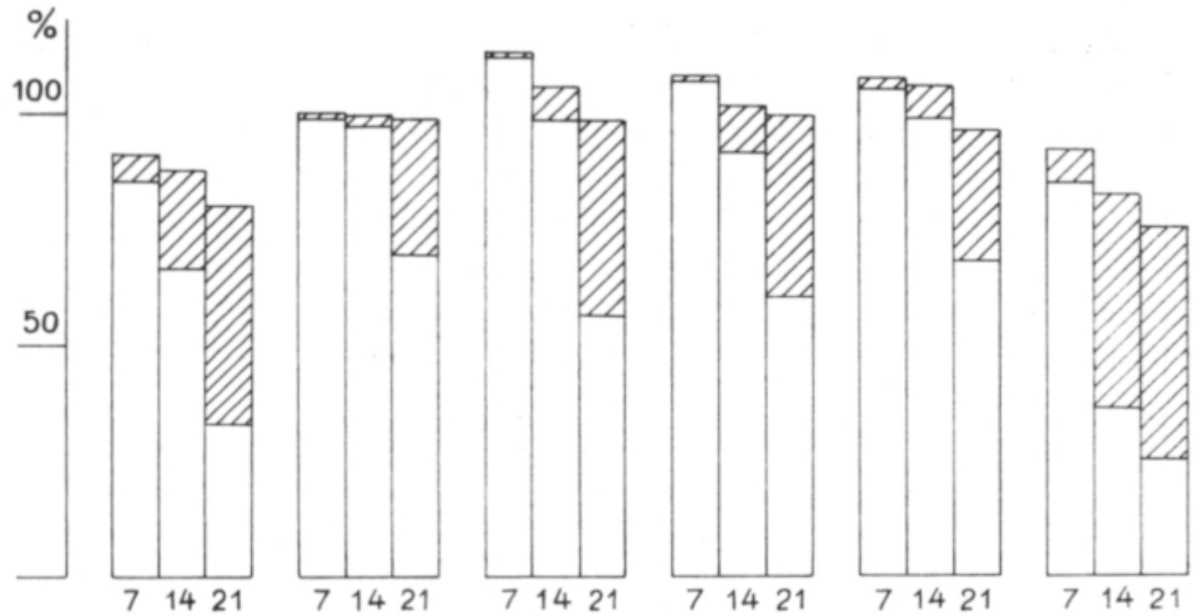

Varastointiaika vrk

Length of storage, days

Käsittelemätön

Muovi
$P V$-bags

Vesi $2^{\circ}$

Vesi $15^{\circ}$

SD 4901

Jäähile

Untreated

Water $2^{\circ} \mathrm{C}$ Water $15^{\circ} \mathrm{C}$

$50 \mathrm{ppm}$

Crushed ice

Kuva 1. Herttaässä-salaatin varastoinnin tulokset $1-2^{\circ}$ koekellarissa v. 1965. Pylvään kokonaispituus esittää koe-erän painoa (\% alkuperäisestä painosta) eri pituisten varastointijaksojen päätyttyä ja pylvään viivoitettu osa sitä määrää, joka kunnostuksen yhteydessä poistettiin.

Fig. 1. The results of storage of Passe Partout lettuce in 1965. Storage temperature $1-2^{\circ} \mathrm{C}$. The length of the column shows the weight (\% of original weight) of the lettuce after 7,14 and 21 days' storage period and the shadowed part of the column the trimming losses.
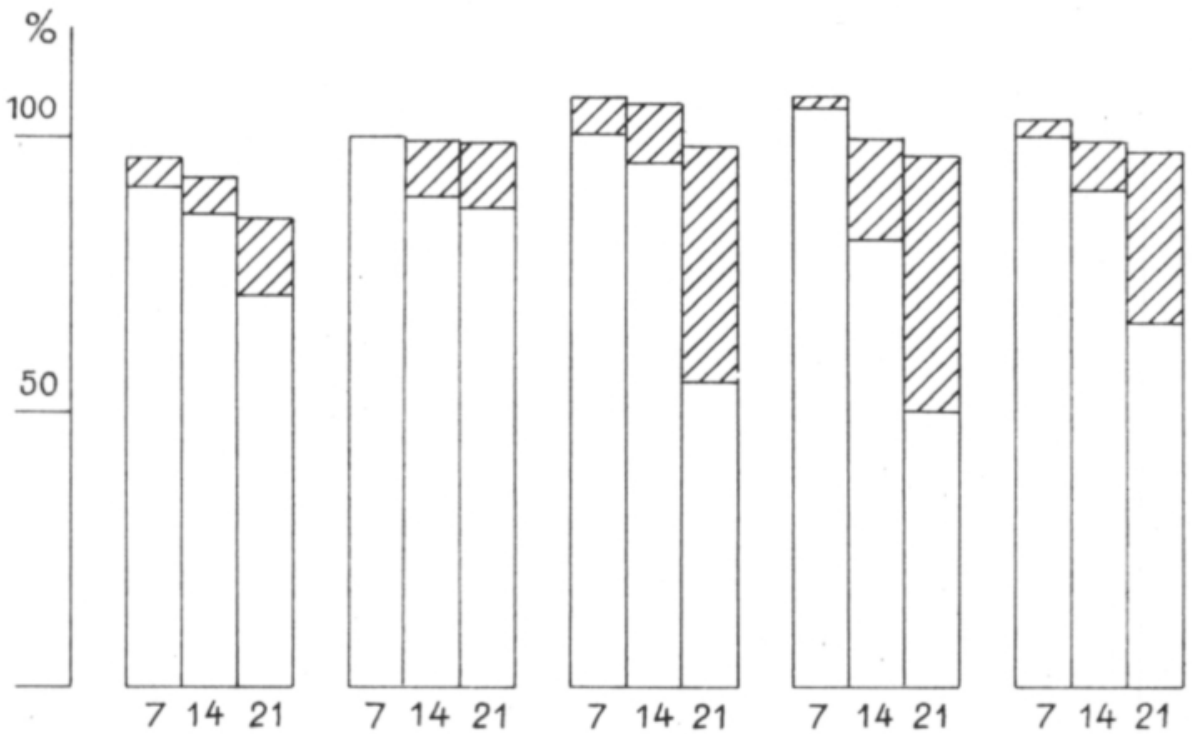

Varastointiaika vrk

Length of storage, days

Käsittelemätön

Muovi

Vesi $2^{\circ}$

Vesi $15^{\circ}$

SD 4901

Untreated PV-bags

Water $2^{\circ} \mathrm{C}$

Water $15^{\circ} \mathrm{C}$

$50 \mathrm{ppm}$

Kuva 2. Great Lakes-lajikkeen varastoinnin tulokset (kuten kuvassa 1).

Fig. 2. The results on Great Lakes lettuce (see Fig. 1). 
Jäähilevarastointia tutkittiin aluksi $1-2^{\circ}$ :n varastossa, ja tulokset osoittivat (taulukko 6), että jäähile heikensi säilyvyyttä kontrollierään verrattuna. Jäähile suli salaattilaatikoissa parin päivän aikana, jolloin se vioitti salaatteja niin, että ne pilaantuivat. Varaston lämpötila alennettiin nyt $0^{\circ}$ :seen; seurauksena oli salaattien jäätyminen ja mustuminen. Tämä johtui siitä, että lämpötila kellarissa vaihteli $-0.5^{\circ}$ :sta $+0.5^{\circ}$ :seen, jolloin jäähile vuoroin suli ja jäätyi. Kolmen viikon kuluttua oli salaattilaatikoitten päällä jääkerros. Tämän jälkeen lämpötila nostettiin $0-1^{\circ}$ : seen, missä saadut tulokset esitetään taulukossa 7 . Herttaässä vaurioitui jään vaikutuksesta osittain, ja sen säilyvyys jäi heikoksi. Great Lakes ei jäätynyt, ja käsittelemättömästä jäähileeseen pakatusta salaatista oli vielä kolmen viikon kuluttua $85 \%$ kauppakelpoista tavaraa.

Taulukko 7. Salaatin jäähilevarastointi v. 1965.

Table 7. Experiment on storing lettuce packed with crushed ice in 1965. Storage temperature $0-1^{\circ} C$.

Prosentit laskettu ennen käsittelyä ja varastointia kunnostetun salaattierän painosta.

Based on the weight of saleable lettuce before treatment and storage.

\begin{tabular}{|c|c|c|c|c|}
\hline \multirow[b]{2}{*}{$\begin{array}{l}\text { Käsittely } \\
\text { Treatment }\end{array}$} & \multirow[b]{2}{*}{$\begin{array}{l}\text { Lajike } \\
\text { Variety }\end{array}$} & \multicolumn{3}{|c|}{$\begin{array}{c}\text { Kunnostetun salaatin paino (\%) varastoinnin } \\
\text { jatkuttua }\end{array}$} \\
\hline & & 7 päivää & $\begin{array}{l}14 \text { päivää } \\
14 \text { days }\end{array}$ & $\begin{array}{l}21 \text { päivää } \\
21 \text { days }\end{array}$ \\
\hline Käsittelemätön + jäähile & Great Lakes & $97.8 \pm 1.45$ & $85.0 \pm 8.05$ & $85.0 \pm 9.62$ \\
\hline Untreated + crushed ice & Herttaässä & $77.3 \pm 22.33$ & $47.8 \pm 34.48$ & $40.5 \pm 6.96$ \\
\hline Kylmävesikäsittely + jäähile & Great Lakes & $113.0 \pm 0.71$ & $95.0 \pm 16.3$ & $85.6 \pm 10.99$ \\
\hline Hydrocooling + crushed ice & Herttaässä & - & $44.9 \pm 40.10$ & $21.6 \pm 18.55$ \\
\hline $\begin{array}{l}\text { Pesu } 15^{\circ} \text { :lla vedellä }+ \text { jäähile } \\
\text { Washed with } 15^{\circ} \mathrm{C} \text { water }+ \text { crushed } \\
\text { ice }\end{array}$ & Great Lakes & $105.2 \pm 1.22$ & $89.5 \pm 8.13$ & $76.9 \pm 14.99$ \\
\hline
\end{tabular}

Taulukko 8. Salaatin (Market Favorite) varastointi vv. 1964-65.

Table 8. Experiment on storing lettuce (Market Favorite) in 1964-65. Storage temperature $1-2^{\circ} \mathrm{C}$ and relative humidity $90-95 \%$.

Prosentit laskettu ennen varastointia kunnostetun salaattierän painosta.

Based on the weight of soleable lettuce before storage.

\begin{tabular}{|c|c|c|c|c|c|c|c|c|c|}
\hline \multirow{3}{*}{$\begin{array}{l}\text { Vuosi } \\
\text { Year }\end{array}$} & \multicolumn{3}{|c|}{$\begin{array}{l}\text { Kunnostetun salaatin paino (\%) varastoinnin } \\
\text { jatkuttua } \\
\text { Percentage of lettuce saleable after storage period of }\end{array}$} & \multicolumn{6}{|c|}{$\begin{array}{c}\text { Varastointitappiot }(\%) \\
\text { Storage losses (\%) }\end{array}$} \\
\hline & 7 päivàä & 14 päivää & 21 päivää & \multicolumn{3}{|c|}{$\begin{array}{c}\text { Kokonais } \\
\text { Total }\end{array}$} & \multicolumn{3}{|c|}{$\begin{array}{l}\text { Haihdunta } \\
\text { Evaporation }\end{array}$} \\
\hline & 7 days & 14 days & 21 days & 7 & 14 & 21 & 7 & 14 & 21 \\
\hline 1964 & $68.3 \pm 11.69$ & $42.2 \pm 9.72$ & $36.0 \pm 12.46$ & 31.7 & 57.8 & 64.0 & 9.0 & 15.5 & 20.8 \\
\hline 1965 & $79.8 \pm 7.20$ & $38.0 \pm 24.37$ & 0 & 20.2 & 62.0 & 100.0 & 11.3 & 30.0 & 34.0 \\
\hline
\end{tabular}


Vuosina 1964 ja 1965 säilytettiin Market Favorite -salaattia käsittelemättömänä $1-2^{\circ}$ :n varastossa. Tappiot olivat kahden viikon kuluttua yli $50 \%$ ja haihtuminen huomattavan suuri (taulukko 8).

\section{Tulosten tarkastelu}

Edellä selostettuja kokeita tarkasteltaessa kiintyy huomio siihen, että eri vuosina oli samalla tavoin käsitellyn ja varastoidun salaatin säilyvyydessä suuria eroja. Kuten alussa mainittiin, oli salaatti ennen varastointia silmävaraisen arvion mukaan tervettä ja tasalaatuista. Vuosina 1964 ja 1965 poikkesivat viljelymenetelmät toisistaan vain kastelun osalta. Vuoden 1964 kasvukausi oli osittain lämmin ja kuiva. Siksi salaattiviljelmiä jouduttiin sadettamaan ja täten aiheutettiin äkillisiä kosteuden muutoksia, joiden vaikutuksesta salaatin lehdenreunatauti kehittyi ja levisi. Vuoden 1964 varastointikokeita lopetettaessa ilmenikin, että lähes kaikki näennäisesti terveenä varastoitu salaatti oli jo korjattaessa taudin saastuttamaa. Ensimmäisen varastointiviikon aikana olivat taudin vahingot vielä vähäiset eikä suuria varastointitappioita tällöin vielä ilmennyt. Toisen varastointiviikon lopussa olivat tappiot jo huomattavia, ja tällöin oli Herttaässän säilyvyys parempaa kuin Great Lakesin tämän edullisemmista ominaisuuksista (kiinteä muoto, paksuhkot lehdet) huolimatta. Olikin todettavissa, että lehdenreunatauti oli vioittanut Great Lakesia pahemmin kuin Herttaässää. Kesä 1965 oli viileä ja kostea eikä salaattiviljelyksellä esiintynyt sadetuksen tarvetta. Lehdenreunatautia ei esiintynyt, ja säilyvyys kahden viikon varastoinnin jälkeen oli varsin tyydyttävä; Great Lakes oli säilynyt paremmin kuin Herttaässä.

Varastoinnin tuloksissa kiinnittyy huomio myös siihen, että salaatin koko ja kehitysaste vaikutti usein varastoinnin lopputulokseen. Tämä käy ilmi mm. Market Favorite-salaatin varastoimistuloksista. Molempina varastointivuosina Market Favorite muodosti kerän, vuonna 1965 hitaasti vain pieniä keriä, joilla oli taipumus vanheta kasvupaikalla nopeasti. Vuonna 1964 oli 150 kerän paino $46 \mathrm{~kg}$, vuonna $196529 \mathrm{~kg}$. Ensimmäisen varastointiviikon jälkeen eivät pienet kerät olleet säilyneet huonommin, mutta toisen ja varsinkin kolmannen varastointiviikon kuluttua nahistuminen aiheutti niissä jopa $62-100 \%$ :n tappioita. Erot eri vuosien välillä olisivat kenties olleet suuremmat, ellei Market Favorite v. 1964 olisi ollut lehdenreunataudin vioittamaa.

Lehdenreunataudin ja nahistumisen lisäksi aiheutti huomattavia tappioita solukkojen kuoleminen kerän sisässä olevissa lehdissä. Tällaista oletettavasti hapen puutteesta johtuvaa vioitusta, jota NELSON (6) ja Rood (7) ovat tarkemmin tutkineet, esiintyi joskus toisen ja varsinkin kolmannen varastointiviikon jälkeen. Kauppakuntoiseksi saattamisen yhteydessä salaatit halkaistiin, jolloin todettiin, että kolmen viikon varastoinnin jälkeen oli tästä syystä noin yksi kerä kymmenestä vioittunut. Vioitusta näytti esiintyvän lajikkeesta, käsittelystä tai salaatin kiinteydestä riippumatta. Kunnostettaessa poistettiin tällä tavoin vioittunut salaatti.

Eri kerranteiden välistä hajontaa lisäsi käsittelyissä salaatinkeriin kertynyt vesi, jota saattoi niistä valua parin ensimmäisen varastointipäivän aikana toisinaan vielä ensimmäisen varastointiviikonkin jälkeen kauppakelpoiseksi kunnostettaessa. 
Suoritettujen kokeiden valossa näyttää siltä, että käsittelemätöntä salaattia voidaan varastoida noin viikon aika. Kahden varastointiviikon kuluttua ovat tappiot vähintään $20 \%$, ja kolmen viikon kuluttua on pehmeä keräsalaatti jo täysin turmeltunutta. Rapea keräsalaatti sen sijaan voi säilyä kolmekin viikkoa, jos se on tervettä ja jos varastointitilat ovat tyydyttävät. Näin pitkän varastoinnin aikana voi kuitenkin edellä kuvattua salaatin sisäisten osien kuolemista esiintyä. Tämän voi todeta vasta keriä halkaistessa.

Salaatin pakkaaminen muoviin pienensi varastoinnin aikana tapahtuvia haihtumistappioita. Niinpä käsittelemättömän Herttaässän haihtumistappiot olivat kolmen viikon varastoinnin jälkeen noin $20 \%$ ja muoviin pakatun Herttaässän vain noin $1-2 \%$. Myös kokonaistappioita vuosina 1963 ja 1965 vähensi muovipakkaus huomattavasti. Vuonna 1964 muovipakkaus taas joudutti Great Lakesin mädäntymistä. Se lienee lähinnä lehdenreunataudin syytä. Muoviin pakatut terveet salaatit voidaan ilmeisesti markkinoida ensimmäisen varastointiviikon jälkeen ilman kauppakelpoiseksi kunnostusta, mutta toisen varastointiviikon jälkeen on tarkistus tarpeen. Muoviin pakattavien salaattien kasteleminen nopeutti mätänemistä.

Molemmat vesikäsittelyt, kylmävesikäsittely sekä pesu 15-asteisella vedellä lisäsivät käsittelemättömään erään verrattuna salaatin säilyvyyttä kahden ensimmäisen varastointiviikon aikana. Nahistumista esiintyi vähemmän kuin kontrollierässä, mutta suurelta osalta johtuu käsittelyjen aiheuttama parempi tulos salaattiin jääneestä vedestä.

Kylmävesikäsittely ei osoittautunut paremmaksi kuin pesu $15^{\circ}$ :n vedellä. Eräissä tapauksissa olivat kylmällä vedellä käsiteltyjen kunnostettujen erien painot suuremmat kuin muiden koejäsenten, mutta se johtuu siitä, että käsittelyn aikana (15 min) oli salaattien lehtiväleihin kertynyt enemmän vettä kuin pesun (15-30 sek) yhteydessä. Jäähdytyksellä ei selostettujen kokeiden mukaan tässä ollut sanottavaa vaikutusta. Tämä poikkeaa mm. Yhdysvalloissa saaduista tuloksista, arvattavasti siksi, että Suomessa harvoin salaatin korjuulämpötila on yli $20^{\circ}$. Sen sijaan Kaliforniassa, jossa asiaa on tutkittu, on vihannesten korjuulämpötila usein yli $30^{\circ}$ (10). Jäähdytyksellä on kenties merkitystä silloin, kun varaston jäähdytyslaitteiden kapasiteetti on riittämätön ja kun varastoon tuodun salaatin lämpö nostaa varaston lämpötilaa.

SD 4901 -käsittelyt paransivat varastoinnin tulosta, ja niiden vaikutus oli kahden ja kolmen viikon varastoinnissa hieman parempi kuin $15^{\circ}$ :n vedellä suoritetun pesun. Salaatin vihreä väri säilyi paremmin SD 4901:llä käsitellyissä kuin muissa koejäsenissä. Kuitenkaan ei ainetta voida suositella käytettäväksi ennen kuin sen vaikutusta ihmisiin ja eläimiin on riittävästi tutkittu.

Alustavat kokeet osoittivat, että käsiteltäessä pehmeätä keräsalaattia jäähileellä varaston lämpötilan säätö vaatii erikoista tarkkuutta. Rapea keräsalaatti ei ole yhtä arkaa jäätymiselle, ja sitä voitaneenkin menestyksellisesti varastoida jäähileeseen pakattuna. Jäähileen merkitys saattaa kuitenkin olla suurin väliaikaisissa varastotiloissa sekä kuljetuksen aikana, jolloin ilman lämpötilaa ja suhteellista kosteutta on vaikea hallita. Tällöin sulava jäähile alentaa lämpötilaa sekä lisää ilman kosteutta, joten salaatin nahistuminen hidastuu. 


\section{Ti $i$ vistel $m \ddot{a}$}

Kylmävesikäsittely, pesu $15^{\circ}$ :n vedellä, SD 4901 -käsittely ja pakkaus muoviin edistivät salaatin (lajikkeet Herttaässä ja Gerat Lakes) säilyvyyttä varastossa, jonka ilman lämpötila oli $1-2^{\circ}$ ja suhteellinen kosteus $90-95 \%$. Kahta viikkoa pitemmässä varastoinnissa oli kunnostetun tavaran määrä suurin muoviin pakatussa salaatissa.

Jäähile soveltui paremmin rapean (Great Lakes) kuin pehmeän (Herttaässä) keräsalaatin esikäsittelyyn.

Great Lakesin säilyvyys käsittelemättömänä oli parempi kuin Herttaässän ja Market Favoriten. Lehdenreunatauti vähentää salaatin sällyvyyttä.

Kahden ja kolmen viikon pituisen varastoinnin aikana esiintyi kerän sisäosien turmeltumista, jota ei päältäpäin voi todeta.

\section{KIRJALLISUUS}

(1.) Соок, J. A. 1953. Cooling lettuce in a cold air blast. Proc. Amer. Soc. Hort. Sci. 62: 422-426.

(2.) El-Mansy, H. I. etc. 1964. Effects of pre- and post-harvest applications of 6-furfurylaminopurine and $\mathrm{N}^{6}$-benzyladenine on physico-chemical changes in lettuce. Plant Physiology 39 (Suppl.): xxxii.

(3.) Friedman, B. A. \& Radspinner, W. A. 1956. Vacuum-cooling fresh vegetables and fruits. United States Dept. of Agriculture. Agric. Marketing Serv. 107: 1-15.

(4.) Dewey, D. H. 1950. Air blast and vacuum cooling of lettuce. Proc. Amer. Soc. Hort. Sci. 56: $320-$ 326.

(5.) Hansen, H. 1963. Uber Untersuchungen mit dem Senescenzinhibitor $\mathrm{N}^{6}$-Benzyladenine (Shellpräparat SD 4901). Die Gartenbauwiss. 28: 463-468.

(6.) Nelson, R. 1926. Storage and transportional diseases of vegetables due to suboxidation. Michigan Agr. Exp. Sta. Tech. Bull. 81: 1-38.

(7.) Rood, P. 1956. Relation of ethylene and postharvest temperature to brown spot of lettuce. Proc. Amer. Soc. Hort. Sci 68: 296-303.

(8.) Rose, D. H., Wright, R. C. \& Whiteman, T. M. 1949. The commercial storage of fruits, vegetables and florists' stocks. United Stated Dept. of Agriculture, Circular 278: 1-60.

(9.) Stewart, J. K. 1955. Heat exchange of lettuce in cartons and other containers. Proc. Amer. Soc. Hort. Sci. 66: $334-338$.

(10.) Stewart, J. K. \& Couey, H. M. 1963. Hydrocooling vegetables. United States Dept. of Agriculture, Marketing Research Report 637: 1-32.

(11.) ZiNK, F. W. 1961. N6-bezyladenine, a senescene inhibitor for green vegetables. Agricultural and Food Chemistry 9: 304-307.

(12.) Vihanneksien, marjojen ja omenien lajittelu- ja pakkausohjeet. 1963. Puutarhatuotteiden standardisoimistoimikunnan julkaisu. $36 \mathrm{~s}$. Helsinki.

\section{SUMMARY :}

STORAGE OF HEAD LETTUCE

IRMA VoIPIO

Institute of Horticulture, University of Helsinki, Viik

The storage of lettuce was studied in 1963-65. The two principal problems were the amount of losses on lettuce during storage of one, two, three or more weeks, and how to reduce storage losses.

The lettuce was grown in experimental fields at Viik (Table 1). To reduce losses during storage the lettuce was pretreated in the following ways before storing. 
1. Hydrocooling by spraying with or by immersion in $2^{\circ} \mathrm{C}$ water for 15 minutes

2. Washing in $15^{\circ} \mathrm{C}$ water for $15-30$ seconds

3. SD 4901 -treatment for $15-30$ seconds

4. Wrapping in perforated PV-bags

5. Crushed ice treatment, 2 litres ice in each box.

Each treatment consisted of 5 replications and each replication of 10 (Passe Partout, Market Favorite) or 8-10 (Great Lakes) heads. The lettuce was trimmed before the treatment and again after storage. The storage temperature was $1-2^{\circ} \mathrm{C}$ and the relative humidity $90-95 \%$.

The results of the experiments are given in Tables 2 to 8 . Treatments $1,2,3$ and 4 (see above) reduced the storage losses as compared with untreated lots during storage of one and two weeks (Tables 2, 4, 5 and 6). Wrapping in PV-bags gave the best results during storage longer than two weeks (Tables $2,6)$.

Great differences in the keeping quality of lettuce occurred in the years 1964 and 1965 . The growing season in 1964 was hot and dry, and the lettuce was irrigated several times. The rapid change in soil moisture during the hot weather may have caused the tip burn in the lettuce. Despite the stored lettuce being stored apparently healthy in 1964, after storage it proved to be affected by this disease. Summer 1965 was cool and wet and no tip burn was found in the lettuce. In 1965 the lettuce thus remained marketable in storage for a longer time than in 1964.

Trimming after a storage period of two and three weeks revealed that one out of ten heads was injured by suboxidation. The damage could not be noticed on the outside. 